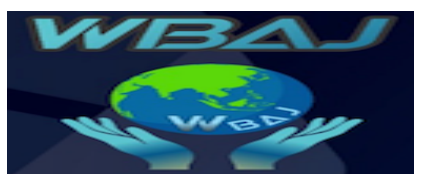

Volume 2 Issue 2, Desember 2020

https:// ejournal.unsub.ac.id/index.php/bisnis

\title{
Kinerja Pegawai Penyaluran Kredit Pensiunan Pada Bank Saudara Kantor Cabang Pembantu Subang
}

\author{
Reza Ronaldo ${ }^{1}$ \\ Sekolah Tinggi Ekonomi dan Bisnis Islam Lampung \\ rezaronaldo19967@gmail.com
}

Kusman Yuhana ${ }^{2}$

Fakultas Ilmu Administrasi Universitas Subang

kusmanyuhana.jurnal@gmail.com

Ade Suparman ${ }^{3}$

Fakultas Ilmu Administrasi Universitas Subang

suparmanade09@gmail.com

\begin{abstract}
Abstrak
Kinerja pegawai Bank Saudara Cabang Subang dalam penyaluran kredit pensiun merupakan kemampuan Bank Saudara Cabang Subang termasuk didalamnya kinerja pimpinan, kinerja pegawai dan staf-stafnya dalam menjalankan fungsi dan tugas dalam mencapai tujuan yang ingin dicapai sesuai dengan visi, misi, tujuan dan sasarannya. Kredit pensiun/pembiayaan yang diberikan oleh perbankan kepada nasabah yang fleksibel tapi belum maksimum. Penelitian dilakukan untuk mengetahui bagaimana kinerja pegawai dalam penyaluran Kredit pension pada Bank saudara Cabang Subang. Penelitian dilakukan di wilayah kerja Bank Saudara Cabang Subang dengan menggunakan pendekatan penelitian kualitatif. Penentuan informan melalui teknik Purposive Sampling yaitu jenis sampel yang pemilihannya didasarkan atas kriteria tujuan dan manfaatnya. Serta yang dijadikan informan adalah Kepala cabang !masyarakat. Teknik pengumpulan data meliputi wawancara mendalam dan observasi. Validitas data dengan menggunakan Triangulasi Data. Teknis analisi data meliputi reduksi data,penyajian dan penarikan kesimpulan. Berdasarkan penelitian, diperoleh hasil bahwa kinerja pegawai dalam penyaluran kredit pensiun Bank saudara cabang Subang diukur menggunakan indikator yaitu produktivitas, kualitas layanan, responsivitas, responsibilitas dan akuntabilitas. Dan indikator tersebut responsivitas yang masih perlu ditingkatkan karena masyarakat masih merasa respon yang diberikan kepada masyarakat masih dirasa kurang optimal.
\end{abstract}

Kata Kunci: Kinerja Pegawai, Kredit pensiun 


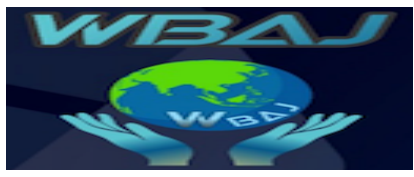

Volume 2 Issue 2, Desember 2020

https://ejournal.unsub.ac.id/index.php/bisnis

\begin{abstract}
The purpose of this research is to conduct research to determine the effect of retirement lending fund in the Bank Saudara Branch Subang that service quality on customer satisfaction is low. Because of that problems the writer is curios to study that problem by this research, authors use qualititative methods to approach explanation. Bank Saudara employee performance Branch Subang retired in lending is the Bank's ability Saudara Branch Subang including performance management, employee performance and its staff in carrying out the functions and tasks in achieving the objectives to be achieved in accordance with the vision, mission, goals and objectives. Pension credit / financing granted by banks to customers flexible but not the maximum. The study was conducted to determine how the employee's performance in the distribution of pension Credit Bank Saudara Branch Subang. Research carried out in the region of the branch corm using qualitative research approaches. Determination of informants through purposive sampling technique that is the type of samples whose election is based on objective criteria and benefits. As well as being used as informants is the Head of the branch! Community. Data collection techniques include in-depth interviews and observation. The validity of the data using Data Triangulation. Technical analysis of the data include data reduction, presentation and conclusion. Based on research, the result that the performance of employees in the Bank's Saudara pension lending branch Subang measured using indicators such as productivity, quality of service, responsiveness, responsibility and accountability. And the responsiveness of the indicators that still need to be improved because people still feel the response given to the community is still considered less than optimal.
\end{abstract}

Keywords: employee performance, Credit pensions

\title{
Pendahuluan
}

Era globalisasi merupakan sebuah kenyataan yang tidak dapat dipungkiri lagi. Indonesia adalah salah satu negara yang sudah merasakan dampaknya. Hal itu dapat dirasakan di berbagai bidang. Salah satunya adalah di bidang ekonomi. Menghadapi era globalisasi, perlu adanya pembangunan di bidang ekonomi, yang diarahkan guna mencapai masyarakat makmur dan berkeadilan sosial yang menjamin kesejahteraan baik materil maupun spiritual sesuai dengan sasaran utama pembangunan. Sisi lain dari perkembangan dan perubahan yang diakibatkan oleh globalisasi yang mempengaruhi seluruh aspek kehidupan seperti disektor ekonomi, menjadikan para pelaku birokrasi perbankan semakin ditantang dan dituntut untuk meningkatkan kulitas dan kuantitas pelayanannya kepada nasabah. Pelayanan mempunyai ruang lingkup yang beragam di kehidupan masyarakat yang luas dan komplek. Kinerja organisasi yang baik sangat berpengaruh terhadap pelayan yang mengutamakan kepuasan pelanggan. Orgnisasi bisnis merupakan pelaksanan perusahaan dan pelayanan kepada nasabah. Organisasi bisnis mempunyai peran yang sangat penting dalam sistem perusahaan karena disini organisasi bisnis terutama sektor perbankan berhubungan langsung dengan nasabah. 


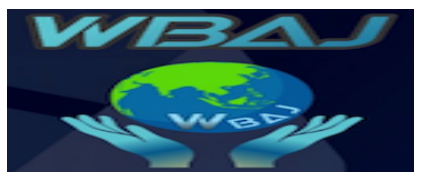

Volume 2 Issue 2, Desember 2020

https://ejournal.unsub.ac.id/index.php/bisnis

Kinerja dalam organisasi bisnis pun harus tercipta dengan baik agar dalam penyelenggaraan dapat berjalan efektif dalam melayani nasabah. Oleh karena itu pelayanan birokrasi disektor bisnis juga diharapkan mengikuti perubahan-perubahan yang terjadi secara cepat dan dinamis sebagaimana yang terjadi di masyarakat. Salah satu organisasi yang bergerak di bidang jasa adalah bank. Berdasarkan UndangUndang No. 7 tahun 1992 tentang Perbankan sebagaimana telah diubah dengan Undang-Undang Nomor 10 tahun 1998, Bank adalah badan usaha yang menghimpun dana dar i masyarakat dalam bentuk simpanan dan menyalurkannya kepada masyarakat dalam bentuk kredit atau bentuk-bentuk lainnya dalam rangka meningkatkan taraf hidup rakyat banyak. Kinerja Bank Saudara Kantor Cabang Pembantu Subang dalam penyaluran kredit merupakan kinerja seluruh karyawan Bank Saudara Kantor Cabang Pembantu Subang termasuk di dalamnya kinerja pimpinan, kinerja pegawai dan staf-stafnya dalam mejalankan fungsi dan tugas dalam mencapai tujuan yang ingin dicapai sesuai dengan visi, misi, tujuan dan sasarannya. Bank Saudara Kantor Cabang Pembantu Subang melaksanakan tugasnya dalam penyaluran Kredit merupakan penyediaan uang atau tagihan yang dapat dipersamakan dengan itu, berdasarkan persetujuan dan kesepakatan pinjam meminjam antara Bank dengan pihak lain yang mewajibkan untuk melunasi hutangnya setelah jangka waktu tertentu.

Bank Saudara Kantor Cabang Pembantu Subang melaksanakan tugasnya dalam penyaluran kredit merupakan kredit atau pembiyaan yang diberikan oleh perbankan kepada nasabah yang feasible tapi belum bankable, maksudnya adalah usaha tersebut memiliki prospek bisnis yang baik dan memiliki kemampuan untuk mengembalikan. Produk pinjaman yang tersedia di Bank Saudara adalah kredit pegawai, kredit pensiunan, kredit untuk pekerja, kredit usaha kecil dan mikro, kredit waralaba, kredit THT. Tetapi produk pinjaman yang tersedia di Bank saudara kantor cabang pembantu subang adalah kredit pensiun dan kredit pegawai. Kredit yang Penyaluran kredit dapat dilakukan langsung, maksudnya dapat langsung mengakses di Kantor Cabang atau Kantor Cabang Pembantu Bank Pelaksana untuk lebih mendekatkan pelayanan kepada nasabah.

Dalam rangka mengkoordinasi program kredit, perusahaan membentuk komite kebijakan.Dibentuk berdasarkan keputusan menko perekonomian tentang komite kebijakan penjaminan kredit atau pembiyaan kepada nasabah.Kementrian koodinator bidang perekonomian bersama dengan instansi pembinaan mengkoordinasikan kebijakan penjaminan kredit. Hal-hal yang dikoordinasikan:

a. Penyedian kredit sesuai dengan kewenangan instansi Pembina.

b. Kebijakan dan prioritas bidang usaha

c. Pembinaan dan pendampingan kredit pensiunan

d. Sosialisasi program dan koordinasi dengan daerah

e. Kebijakan penjaminan kredit

\section{Kerangka Teori}

Konsep Kinerja

Dalam bahasa inggris kinerja di padankan dengan istilah performance yang berarti sesuatu hasil yang telah dikerjakan. Pengertian kinerja atau performance menurut 


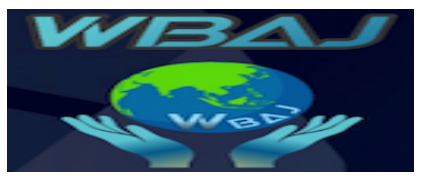

Volume 2 Issue 2, Desember 2020

https://ejournal.unsub.ac.id/index.php/bisnis

Prawirosentono (1999:2) : "Kinerja atau performance adalah hasil kerja yang dapat dicapai oleh seseorang atau sekelompok orang dalam suatu organisasi, sesuai dengan wewenang dan tanggung jawab masing-masing, dalam rangka upaya mencapai tujuan organisasi bersangkutan secara legal, tidak melanggar hukum dan sesuai dengan moral maupun etika".

Menurut Soekanto (1993:365), kinerja adalah cara bagaimana melaksanakan suatu kegiatan dan hasil dari kegiatan tersebut (hasil kerja). Sedangkan menurut Namawi (2000:396) kinerja dapat diartikan sebagai proses organisasi dalam melakukan penelitian terhadap pegawai atau karyawan dalam melaksanakan pekerjaannya.Sedangkan Menurut Widodo (2008:78) mengemukakan bahwa kinerja adalah melakukan suatu kegiatan dan menyempurnakannya sesuai dengan tanggung jawabnya dengan hasil yang diharapkan. Sedangkan Mahsun memberi pengertian (2006:5) kinerja (performance) adalah mengenai tingkat pencapaian pelaksanaan suatu kegiatan atau program atau kebijakan dalam mewujudkan sasaran, tujuan, visi dan misi yang tertuang strategi perencanaan suatu organisasi. Kemudian Widodo (2005: 78) berpendapat kinerja adalah melakukan suatu kegiatan dan menyempurnakannya sesuai dengan tanggung jawabnya dengan hasil seperti yang diharapkan, atau suatu hasil karya yang dapat dicapai seseorang atau kelompok orang dalam suatu organisasi sesuai dengan wewenang dan tanggungjawabnya masing-masing dalam rangka mencapai tujuan organisasi bersangkutan secara legal tidak melanggar hokum, dan sesuai dengan moral dan etika.

Kemudian Bastian (dalam Hessel Nogi, 2005:175) mendefinisikan kinerja organisasi sebagai gambaran mengenai tingkat pencapain pelaksanaan tugas dalam satu organisasi, dalam upaya mewujudkan sasaran, tujuan, misi dan visi organisasi. Yuworo, dkk (dalam Hessel Nogi, 2005:178) mengatakan bahwa konsep kinerja organisasi berhubungan dengan berbagai aktivitas dalam rantai nilai (value chain) yang ada pada organisasi. Definisi kinerja dalam hal ini tentu saja, diambil dari sistem ukuran kinerja yang dinilai secara objektif, realistis, dan keilmuan yang sesuai tentang apa yang dikerjakan dan yang tidak dikerjakan dalam sektor bisnis. Dari beberapa definisi diatas dapat disimpulkan bahwa kinerja organisasi adalah kemampuan organisasi dalam menjalankan tugas sesuai dengan sasaran, visi dan misi dalam mencapai tujuan yang ingin dicapai.

Pengertian kinerja telah di rumuskan oleh beberapa ahli (dalam Tika, 2006:121) antara lain sebagai berikut:

1. Stoner dalam bukunya yang berjudul "management" mengemukakan bahwa kinerja adalah fungsi dari motivasi, kecakapan dan persepsi peranan.

2. Benardin dan Russell secara definitive menjelaskan kinerja merupakan catatan out come yang dihasilkan dari fungsi pegawai tertentu atau kegiatan yang dilakukan selama periode waktu tertentu. Kinerja suatu jabatan secara keseluruhan sama dengan jumlah (rata-rata) dari kinerja fungsi pegawai atau kegiatan yang dilakukan.

3. Handoko mendefinisikan kinerja sebagai proses dimana organisasi mengevaluasi atau menilai prestasi kerja karyawan.

4. Prawiro Suntoro mengemukakan bahwa kinerja adalah hasil kerja yang dicapai seseorang atau sekelompok orang dalam suatu organisasi dalam rangka mencapai tujuan dalam periode waktu tertentu. 
Dari beberapa definisi kinerja yang telah disebutkan diatas, maka unsur-unsur yang tedapat dalam kinerja adalah sebagai berikut:

1. Hasil-hasil fungsi pekerjaan

2. Faktor-faktor yang berpengaruh terhadap prestasi kerja pegawai, seperti motivasi, kecakapan, persepsi peranan, dan sebagainya

3. Pencapaian tujuan organisasi

4. Periode waktu tertentu

Berdasarkan uraian diatas, maka dapat disimpulkan bahwa kinerja adalah hasil kerja yang dapat dicapai seseorang atau sekelompok orang dalam suatu organisasi sesuai dengan hasil yang diharapkan dalam rangka mencapai tujuan organisasi dalam periode waktu tertentu.

Dalam bahasa Indonesia kata pegawai berasal dari pe dan gawai. Pe adalah sebuah awalan yang menunjukkan arti orang yang mengerjakan atau mempunyai pekerjaan seperti yang disebutkan oleh kata dasar, sedangkan gawai berarti kerja yang berawal dari bahasa jawa. Dengan kata lain pegawai adalah orang yang bekerja pada suatu tempat yang resmi yang memiliki data-data pribadi didalam tempat pekerjaan yang dimaksud adalah organisasi, badan dan lainnya yang berhubungan dengan pegawai. Pegawai adalah orang yang bekerja pada suatu organisasi atau badan secara resmi yang telah memiliki kekuatan hukum.

Menurut Mangkunegara (2006:9) beberapa ahli mendefinisikan pegawai sebagai berikut:

1. Kusriyanto menyatakan kinerja pegawai adalah perbandingan hasil yang dicapai dengan peran serta tenaga kerja persatuan waktu (biasanya per jam).

2. Cardosa menyatakan bahwa kinerja pegawai adalah ungkapan seperti output, efisiensi serta efektivitas sering dibutuhkan dengan produktivitas.

3. Mangkunegara menyatakan kinerja pegawai itu adalah hasil kerja secara kualitas dan kuantitas yang dicapai oleh seorang pegawai dalam melaksanakan tugasnya sesuai dengan tanggungjawab yang diberikan kepadanya.

Dari pendapat para ahli diatas bahwa kinerja pegawai adalah prestasi kerja yang dicapai oleh pegawai pada periode waktu tertentu dalam melaksanakan tugas kerjanya sesuai dengan tanggungjawab yang diberikan kepadanya dalam rangka mencapai tujuan organisasi.

Menurut Hasibuan (2002:56) kinerja pegawai dapat dikatakan baik ataupun dapat di nilai dari beberapa hal yaitu:

1. Kesetian seorang pegawai dikatakan memiliki kesetian jika ia melakukan tugasnya secara sungguh-sungguh dan penuh tanggung jawab terhadap amanah yang diberikan organisasi. Menurut Syuhadak (1994:76) kesetian adalah tekad dan kesanggupan, mentaati, melaksanakan dan mengamalkan sesuatu yang ditaati dengan penuh kesadaran dan tanggungjawab.

2. Prestasi kerja merupakan hasil kerja yang dicapai pegawai dalam melaksanakan tugas yang dibebankan kepadanya. Pada umumnya prestasi kerja seorang pegawai dipengaruhi oleh kecakapan, keterampilan, pengalaman dan kesanggupan pegawai dalam melaksanakan tugas dan fungsinya. Namun demikian prestasi kerja seorang pegawai tidak hanya tergantung dari kemampuan dan keahlian yang bersangkutan untuk menyelesaikan suatu 
pekerjaan, tetapi juga berhubungan dengan peralatan kerja (dalam Syuhadhak, 1994:74). Artinya dengan peralatan kerja yang semakin baik dan canggih akan menghasilkan prestasi kerja yang semakin baik. Dengan demikian tidak hanya kemampuan untuk menyelesaikan pekerjaan dinilai tetapi kemampuan dalam memanfaatkan peralatan yang ada guna hasil yang lebih baik menjadi ukuran kinerja pegawai.

3. Kedisiplinan sejauh mana pegawai dapat mematuhi peraturan-peraturan yang ada dan melaksanakan intruksi yang diberikan kepadanya. Disiplin dapat diartikan melaksanakan apa yang telah disetujui bersama antara pemimpin dan para pegawai baik persetujuan tertulis, lisan ataupun peraturan-peraturan dan kebiasaan-kebiasaan.

4. Kreatifitas kemampuan pegawai dalam mengembangkan kreatifitas dan mengeluarkan potensi yang dimiliki dalam menyelesaikan pekerjaannya sehingga bekerja lebih berdaya guna dan berhasil guna.

5. Kerja sama diukur dari kemampuan pegawai dalam bekerja sama dengan pegawai lain dalam menyelesaikan suatu tugas yang ditentukan, sehingga hasil pekerjaannya akan semakin membaik.

6. Kecakapan, dapat diukur dari tingkat pendidikan pegawai yang disesuaikan dengan pekerjaan yang menjadi tugasnya.

7. Tanggungjawab adalah kesanggupan seorang pegawai menyelesaikan pekerjaan yang diserahkan kepadanya dengan sebaik-baiknya dan tepat pada waktunya serta berani memikul resiko yang dilakukan.

Berdasarkan pengetian diatas dapat disimpulkan bahwa kinerja pegawai dalam organisasi mengarah kepada kemampuan pegawai dalam melaksanakan keseluruhan tugas-tugas yang menjadi tanggung jawabnya. Tugas-tugas tersebut biasanya berdasarkan indikator-indikator keberhasilan yang sudah ditetapkan. Sebagai hasilnya akan diketahui bahwa seseorang pegawai masuk dalam tingkatan kinerja tertentu. Kinerja merupakan kombinasi antara kemampuan dan usaha untuk menghasikan apa yang dikerjakan. Supaya menghasilkan kinerja yang baik seseorang harus memiliki kemampuan, kemauan usaha agar serta setiap kegiatan yang dilaksanakan tidak mengalami hambatan yang berat suatu dalam lingkungannya.

\section{Penilaian Kinerja Organisasi}

Penelitian kinerja akan menimbulkan perbaikan atau peningkatan kinerja karyawan yang kemudian akan berdampak positif pada kinerja organisasi secara keseluruhan. Definisi yang dikemukakan oleh Mardiasmo (dalam Hessel Nogi, 2005:172) mengemukakan bahwa tolak kinerja organisasi tersebut, karena satuan ukur yang relevan digunakan adalah efesienti pengelolaan dana dan tingkat kualitas pelayanan yang dapat diberikan kepada publik.

James B. Whittaker (dalam Hessel Nogi,171) juga mengemukakan bahwa pengukuran atau penilaian kinerja merupakan suatu alat manajemen yang digunakan untuk meningkatkan kualitas pengambilan keputusan dan akuntabilitas. Penilaian kinerja juga digunakan untuk menilai pencapaian tujuan dan sasaran (goals and objectives).

Sedangkan menurut Larry D. Stout (dalam Hessel Nogi, 2005:174) mengatakan bahwa pengukuran atau penilaian kinerja organisasi merupakan proses mencatat dan mengukur pencapaian pelaksanaan kegiatan dalam arah pencapaian misi (mission 


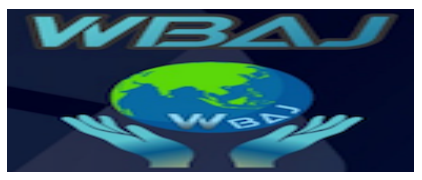

Volume 2 Issue 2, Desember 2020

https://ejournal.unsub.ac.id/index.php/bisnis

accomplishment) melalui hasil-hasil yang ditampilkan berupa produk, jasa, atau pun suatu proses.

Adapun manfaat penilaian kinerja organisasi dikatakan oleh Bastian (dalam Hessel Nogi, 2005:173) akan mendorong pencapaian tujuan organisasi dan akan memberikan umpan balik untuk upaya perbaikan terus-menerus (berkelanjutan). Pengukuran kinerja tidak dimaksudkan untuk berperan sebagai mekanisme dalam memberikan penghargaan atau hukuman (reward/punishment), akan tetapi pengukuran kinerja berperan sebagai alat komukasi dan alat manajemen untuk memperbaiki kinerja.

Penilaian kinerja berhubungan dengan sistem manajemen kinerja. Penerapan sistem manajemen kinerja dalam organisasi akan membawa dampak positif, karena dengan melakukan penilaian terhadap kinerja organisasi baik dari level yang paling rendah maupun level yang paling maupun level yang tertinggi, berpengaruh terhadap manajemen organisasi, kepemimpinan, dan juga meningkatkan kualitas dalam kehidupan kerja karyawan.

\section{Indikator Kinerja}

Secara umum indikator mempunyai fungsi untuk membangun dasar pengukuran, analisis, dan evaluasi kinerja organisasi atau unit kerja. Menurut Bastian dalam Hessel (2005:175) merupakan indikator kinerja oranisasi sebagai berikut:

1. Indikator masukan (inputs), adalah segala sesuatu yang dibutuhkan agar organisasi maupun menghasilkan produknya, baik barang atau jasa, yang meliputi sumber daya manusia, informasi, kebijakan dan sebagainya.

2. Indikator keluaran (outputs), adalah segala sesuatu yang diharapkan langsung dicapai dari suatu kegiatan yang bersifat fisik ataupun nonfisik.

3. Indikator hasil (outcomes), adalah segala sesuatu yang mencerminkan berfungsinya keluaran kegiatan pada jangka menengah (efek langsung).

4. Indikator manfaat (benefit), yaitu sesuatu yang terkait dengan tujuan akhir dari pelaksaan kegiatan.

5. Indikator dampak (impacts), adalah pengaruh yang ditimbulkan, baik positif maupun negative, pada setiap tingkatan indikator berdasarkan asumsi yang telah ditetapkan.

Mohamad Mahsun (2006:71) mengemukakan bahwa indikator kinerja (performance indicators) sering disamakan dengan ukuran kinerja (performance measure ). Namun sebenernya, meskipun keduanya merupakan criteria pngukuran kinerja, terdapat perbedaan makna.Indikator kinerja mengacu pada penilaian kinerja secaratidak langsung yaitu hal-hal yang bersifathanya merupakan indikasi-indikasi kinerja, sehingga bentuknya cenderungkualitatif.Sedangkan ukuran kinerja adalah kriteria kinerja yangmengacu pada penilaian kinerja secara langsung, sehingga bentuknya lebih bersifat kualitatif.

Sedangkan menurut Dwiyanto (2002:50-51) menyatakan indikator untuk mengukur kinerja organisasi meliputi:

Menurut pendapat Dwiyanto (2002:50-51) Yaitu indikator untuk mengukur kinerja organisasi yaitu: produktivitas, kualitas pelayanan, responsivitas, responsibilitas, dan akuntabilitas.

1. Produktivitas. 
Konsep produktivitas tidak hanya mengukur tingkat efisiensi, namun juga mengukur efektifitas pelayanan. Produktivitas pada umumnya dipahami sebagai rasio antara input dan output. Konsep produktivitas diperluas pada seberapa besar pelayanan publik itu memiliki hasil yang diharapkan sebagai salah satu indikator kinerja yang penting (Dwiyanto, 2002:50).

2. Kualitas Pelayanan

Kinerja pelayanan juga dapat dilihat dari kualitas pelayanan yang diberikan organisasi bisnis terhadap nasabah. Karena sekarang ini, kualitas pelayanan menjadi cenderung penting dalam menjelaskan kinerja organisasi pelayanan bisnis. Banyak terjadi kasus ketidak puasaan terhadap kualitas layanan dari suatu organisasi bisnis. Maka dari itu, kepuasaan nasabah terhadap layanan yangdidapat, dapat dijadikan indikator kinerja organisasi bisnis. Penggunaan kepuasan masyarakat menjadi keuntungan karena informasi tentangkepuasan masyarakat menjadi keuntungan karena informasi tentang kepuasan masyarakat sering kali tersedia secara mudah dan murah (Dwiyanto,2002:50).

3. Responsivitas

Responsivitas merupakan kemampuan organisasi untuk mengidentifikasi kebutuhan masyarakat, menyusun prioritas kebutuhan dan mengembangkannya ke dalam berbagai program pelayanan. Responsivitas dimasukkan sebagai salah satu indikator kinerja karena responsivitas secara langsung menggambarkan kemampuaan organisasi bisnis dalammenjalankan misi dan tujuannya, terutama untuk memenuhi kebutuhan masyarakat (Dwiyanto, 2002:50-51).

4. Responsibilitas

Responsibilitas menjelaskan apakah pelaksanaan kegiatan organisasi bisnis dilakukan sesuai dengan prinsip-prisip administrasi yang benar atau sesuai dengan kebijakan organisasi (Dwiyanto, 2002:51).

5. Akuntabilitas

Akuntabilitas binis menunjuk pada seberapa besar kebijakan dan kegiatan organisasi bisnis tunduk pada para pejabat politik yang dipilih rakyat.Kinerja organisasi bisnis tidak hanya bisa dilihat dari ukuran internal yang dikembangkan oleh organisasi bisnis seperti pencapaian target.Kinerja sebaiknya harus dinilai dari ukuran eksternal, seperti nilai-nilai dan norma-norma yang berlaku dalam masyarakat. Suatu kegiatan organisasi bisnis memiliki akuntabilitas yang tinggi kalau kegiatan organisasi itu dianggap benar sesuai dengan nilai dan norma yang berkembang dalam masyarakat. (Dwiyanto, 2002:51).

\section{Faktor-faktor yang mempengaruhi kinerja}

Dalam menilai kinerja organisasi tidak lepas dari faktor-faktor dari dalam maupun yang ada disekeliling oragnisasi yang dapat mempengaruhi kinerja organisasi tersebut. Menurut Mahmudi (2005:21) kinerja merupakan suatu konstruk multi dimensional yang mencakup banyak faktor yang mempengaruhinya. Faktor-faktor yang mempengaruhi kinerja adalah:

1. Faktor personal atau individual, meliputi: pengetahuan, keterampilan, kemampuan, kepercayaan diri, motivasi, dan komitmen yang dimiliki oleh setiap individu. 


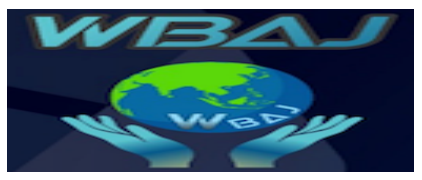

Volume 2 Issue 2, Desember 2020

https://ejournal.unsub.ac.id/index.php/bisnis

2. Faktor kepemimpinan, meliputi: kualitas dalam memberikan dorongan, semangat, arahan dan dukungan yang diberikan manajer dan team leader.

3. Faktor tim, meliputi: kualitas dukungan dan semangat yang diberikan oleh rekan dalam satu tim, kepercayaan terhadap sesama anggota tim, kekompakan dan keeratan anggota tim.

4. Faktor sistem, meliputi: sistem kerja, fasilitas kerja atau insfrastruktur yang diberikan oleh organisasi, proses organisasi, dan kultur kinerja dalam organisasi.

5. Faktor kontekstural, meliputi: tekanan dan perubahan lingkungan eksternal dan internal.

Menurut Soesilo dalam Hessel (2005:180) mengemukakan bahwa kinerja suatu organisasi di masa depan dipengaruhi oleh faktor-faktor berikut:

1. Struktur organisasi sebagai hubungan internal yang berkaitan dengan fungsi yang menjalankan aktivitas organisasi.

2. Kebijakan pengelolaan, berupa visi dan misi organisasi.

3. Sumber daya manusia, yang berkaitan dengan kualitas karyawan untuk bekerja dan berkarya secara optimal.

4. Sistem informasi manajemen, yang berhubungan dengan pengelolaan data baseuntuk digunakan dalam mempertinggi kinerja organisasi.

5. Sarana dan prasarana yang dimiliki, yang berhubungan dengan penggunaan teknologi bagi penyelenggara organisasi pada setiap aktivitas organisasi.

Ruky dalam Hessel (2005:180) mengidentifikasi faktor-faktor yang berpengaruh langsung terhadap tingkat pencapaian kinerja organisasi sebagai berikut:

1. Teknologi yang meliputi peralatan kerja dan metode kerja yang digunakan untuk menghasilkan produk atau jasa yang dihasilkan oleh organisasi. Semakin berkualitas teknologi yang digunakan maka akan semakin tinggi tingkat kinerja organisasi tersebut.

2. Kualitas input atau material yang digunakan oleh organisasi.

3. Kualitas lingkungan fisik yang meliputi keselamatan kerja, penataan ruangan dan kebersihan.

4. Budaya organisasi sebagai pola tingkah laku dan pola kerja yang ada dalam organisasi yang bersangkutan.

5. Kepemimpinan sebagai upaya untuk mengendalikan anggota organisasi agar bekerja sesuai dengan standrt dan tujuan organisasi.

6. Pengelolaan sumber daya manusia yang meliputi aspek kompensasi, imbalan, promosi, dan lain-lain.

Sementara itu, Dale timpe (1992:329-330) menyebutkan tiga penentu kinerja organisasi yaitu tingkat keterampilan, tingkat upaya dan kondisi eksternal.Sehingga dapat diambil kesimpulan bahwa faktor yang mempengaruhi kinerja organisasi dapat ditujukan pada faktor sumber daya manusia, struktur organisasi dan komunikasi organisasi.

\section{Kredit Pensiunan}

Kredit adalah penyedian uang atau tagihan yang dapat dipersamakan dengan itu, berdasarkan persetujuan dan kesepakatan pinjam meminjam antara bank dengan pihak lain yang mewajibkan pihak peminjam untuk melunasi hutangnya setelah jangka waktu tertentu dengan pemberian bunga. 


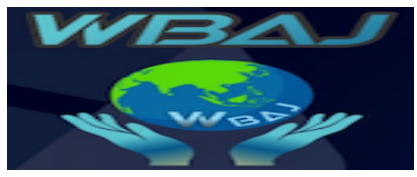

Volume 2 Issue 2, Desember 2020

https://ejournal.unsub.ac.id/index.php/bisnis

Ketentuan dalam kredit pensiunan:

1. Angsuran pinjaman perbulan ditetapkan maksimum $90 \%$ dari gaji pensiun.

2. Cicilan bulanan dipotong dari gaji pensiun.

3. Plafond pinjaman mulai Rp 5.000.000,00

4. Biaya Provisi $1 \%$.

5. Biaya Administrasi.

6. Retensi 1 kali angsuran.

7. Asuransi tergantung usia, jangka waktu kredit dan flafond.

\section{Metode Penelitian}

Suatu penelitian sosial pada dasarnya diharapkan dapat mengungkapkan fenomena tertentu serta menghasilkan kesimpulan teoritis tentang jalin-menjalinnya gejala atau fenomena. Persoalan penting bagi suatu penelitian adalah mengenai pemilihan metodologinya akan menentukan derajat keberhasilan penelitian. Metode yang digunakan dalam penelitian ini adalah metode deskriptif analitik dengan teknik pendekatan secara kualitatif. Tujuan penelitian tipe deskriptif adalah mendeskripsikan secara terperinci fenomena sosial tertentu guna mendapatkan fenomena yang lebih mendalam maka digunakan metode kualitatif. Menurut bogdan dan taylor dalam moleong (2001:3) disebutkan bahwa metode penelitian deskriptif kualitatif merupakan prosedur penelitian yang menghasilkan data deskriptif berupa kata-kata tertulis atau lisan dari orang-orang dan perilaku yang diamati yang selanjutnya diinterprestasikan peneliti.

Pemilihan rancangan penelitian deskriptif kualitatif ini dimaksudkan agar peneliti dalam melakukan pendekatan terhadap obyek penelitian akan dilakukan secara wajar dalam artian menggali informasi sesuai dengan persepsi peneliti dan informan, dan proses penggalian informasi ini dapat berkembang sesuai dengan interaksi yang terjadi dalam proses wawancara. Adapun alasan peneliti menggunakan metode tersebut adalah agar dapat mengumpulkan sebanyak mungkin informasi mengenai fakta-fakta yang menyebabkan kurang optimalnya kinerja layanan bagian kredit dalam penyaluran kredit pada Bank Saudara Kantor Cabang Pembantu Subang. Informasi yang diperoleh tersebut diharapkan mampu memberikan pemahaman yang lebih mendalam tentang fakta-fakta yang menyebabkan kurang optimalnya kinerja layanan bagian kredit dalam penyaluran kredit pada Bank Saudara Kantor Cabang Pembantu Subang.

\section{Hasil dan Pembahasan}

\section{Sejarah Bank Saudara ( Persero )}

Bank Saudara adalah salah satu bank yang ada di Indonesia. Bank ini didirikan pada tahun 1906. Bank ini berkantor pusat di Bandung. Pada tahun 1906 Himpoenan Soedara berdiri atas prakarsa 10 saudagar pasarbaru, tahun 1913 disahkan sebagai 


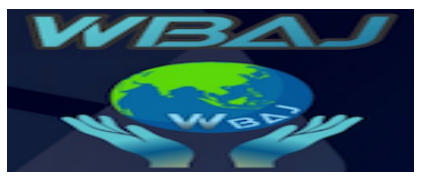

Volume 2 Issue 2, Desember 2020

https://ejournal.unsub.ac.id/index.php/bisnis

badan hukum berstatus "vereeniging", tahun 1975 menjadi badan hukum dengan nama " PT. Bank Tabungan Himpunan Saudara1906", tahun 1991 Medco Group masuk menjadi pemegang saham pengendali, tahun 1993 beroperasi sebagai Bank Umum dengan nama "PT. Bank HS 1906" yang diikuti perubahan logo, tahun 2006 identitas korporat berubah dari Bank HS 1906 menjadi Bank Saudara sekaligus menjadi perusahaan publik atau terbuka, tahun 2007 perubahaan susunan pengurus perseroan serta penambahan layanan menjadi salah satu Bank Kustodian, tahun 2008 izin beroperasi menjadi bank devisa, tahun 2009 Bank saudara melakukan Penawaran Umum Terbatas-I (PUT-I) dengan Hak Memesan Efek Terlebih Dahulu (HMETD) sejumlah 750.000.000 (tujuh ratus lima puluh juta) saham, dengan nilai nominal Rp. 100 (Seratus rupiah), tahun 2011 penerbitan obligasi bank saudara I tahun 2011 dalam rangka mengembangkan pasar kredit di Indonesia, bank saudara I tahun 2011 senilai Rp 250 miliar yang listing di bursa efek Indonesia tanggal 2 desember 2011, tahun 2012 pada 29 oktober 2012 bank saudara menerbitkan obligasi subordinasi bank saudara II tahun 2012 sebesar Rp 300 miliar. Tahun 2013 Grand Opening Gedung Bank Saudara sekaligus bertepatan dengan HUT Bank Saudara ke 107 pada 18 April 2013. Kantor pusat Bank Saudara yang semula di jalan Buah Batu No.58 Bandung kemudian pindah ke gedung Bank Saudara di jalan Dipenogoro No.28 Bandung. PT. Bank Himpunan Saudara 1906 Tbk, telah memperoleh persetujuan dari bank Indonesia.

Dengan telah diundangkannya Undang - Undang No.7 Tahun 1992 sebagaimana telah diubah dengan undang-undang No. 10 tentang perbankan pada tanggal 25 Maret 1992, maka berdasarkan pasal 21 ayat 1 Undang-undang No.7 Tahun 1992 tersebut, suatu bank umum di Indonesia harus salah bentuk hukum tersebut dibawah ini :

1. Perusahaan Umum (PERSERO)

2. Perusahaan Daerah

3. Perseroan Terbatas

Sehubungan dengan hal itu Bank Saudara sebagai bank umum yang didirikan dengan undang-undang nomor 21 tahun 1968 harus menyesuaikan bentuk hukumnya menurut undang-undang perbankan yang baru tersebut. Sebagai dasar peralihan bentuk badan hukum tersebut adalah peraturan pemerintah Nomor 21 Tahun 1992 tentang penyesuaian bentuk hukum Bank Saudara menjadi perusahaan perseroan, dimana peralihan bentuk hukum menjadi perseroan ini tidak mengubah statusnya sebagai Badan Usaha Milik Negara.

Penyesuaian bentuk badan hukum Bank Saudara menjadi persero pada dasarnya adalah penggantian dasar pendirian yang semula berdasarkan undang-undang menjadi dalam bentuk akta otentik pendirian perseroan terbatas sebagaimana diatur dalam kitab Undang - Undang Hukum Dagang. Sejalan dengan bentuk hukum perseroan tersebut, telah ditetapkan modal dasar perseroan Rp. 5.000.000.000.000.- ( lima triliyun ) terbagi dalam Rp. 2.000.000.- (dua juta) lembar saham, masing -masing saham dengan nominal sebesar Rp. 500.000 ( lima ratus ribu). Dari modal dasar tersebut telah diambil bagian/ di tetapkan dalam kas perseroan sebanyak Rp 500.000.(lima ratus ribu) lembar saham, dimana 99,99\% saham yang dimaksud dikusai oleh Negara Republik Indonesia. 


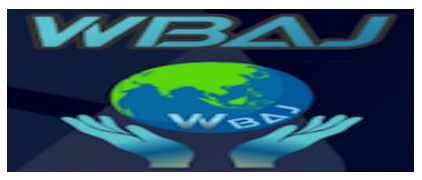

Volume 2 Issue 2, Desember 2020

https://ejournal.unsub.ac.id/index.php/bisnis

Dengan demikian sebagai akibat beralihnya bentuk hukum menjadi perseroan sesuai dengan pasal 1 akta pendirian No.133 tertanggal 31 juli 1992, maka yuridis penyebutan Bank Himpunan Saudara sebagai perseroan adalah perusahaan Perseroan (Persero) PT. Bank Himpunan Saudara yang selanjutnya disingkat PT. Bank Saudara (Persero). Namun penyebutan sehari-hari untuk tujuan marketing atau promosi tetap digunakan sebutan Bank Saudara.

Bank Saudara dengan prinsip organizing sebagai salah satu fungsi manajemen dalam mengatur dan menentukan sistem alokasi, pemanfaatan, pendayagunaan dan koordinasi sumber daya pengarahan secara efisinsi untuk menunjang pencapaian sasaran usaha dan bisnis secara optimal.

Visi, Misi Bank Saudara (Persero) Tbk. Kantor Cabang Pembantu Subang adalah "Menjadi Bank komersial terkemuka yang selalu mengutamakan kepuasan nasabah". Visi :Pelopor institusi keuangan yang menjadi bank berkinerja baik dan sehat.

Misi : Memenuhi harapan stakeholder dalam usaha perbankan melalui 5 pilar:

1. Menjaga Kepercayaan Masyarakat

2. Memberikan Pelayanan Secara Personal

3. Peningkatan Kualitas Manajemen Dan Operasional Perbankan

4. Melestarikan Usaha Perbankan Dengan Nilai-Nilai Tata Kelola Perusahaan (Good Corporate Governance) Yang Baik

5. Pelopor Jasa Keuangan Yang Berkembang Inovatif.

Kinerja Pegawai Dalam Penyaluran Kredit Pensiun Bank Saudara Cabang Subang Penilaian suatu kinerja dalam organisasi dapat dijadikan sebagai ukuran keberhasilan suatu organisasi dalam mecapai misi yang ditetapkan. Sehingga penilaian kinerja sangat dianggap peting. Suatu pelayanan yang optimal adalah jika didalamnya terdapat indikator - indikator yang digunkan untuk tolak ukur keberhasilan.

Dalam bab ini akan dibahas tentang hasil dan pembahasan dalam penelitian tentang bagaimana kenerja penyaluran kredit pada Bank Saudara ( persero) Tbk. Cabang subang untuk mengukur Bank Saudara ( Persero ) Tbk. Cabang subang digunkan indikator produktivitas, kualitas pelayanan, Responsivitas, Responsibilitas dan Akuntabilitas.

\section{Produktivitas}

Produktivitas pada umumnya dipahami sebagai rasio antara input dan aoutput yang dapat di artikan sejauh mana perbandingan antara upaya yang dilakukan dengan hasil yang diperoleh. Dalam penelitian ini produktivitas kinerja penyaluran kredit pada Bank Saudara (Persero) Tbk. Cabang subang meliputi pelayanan yang dikeluarkan oleh Bank Saudara ( persero) Tbk. Cabang subang dalam penyaluran kredit pensiun. Produktivitas bank saudara (persero) Tbk. Cabang subang adalah kemampuan kinerja bank saudara (persero) Tbk. Cabang subang dalam usaha pencapaian hasil yang telah ditetapkan. Produktivitas bank saudara (persero) Tbk cabang subang dapat berupa pencapaian target yang telah ditetapkan berdasarkan permintaan nasabah. Produktivitas di bank saudara (persero) Tbk. Cabang subang dilakukan melalui cara membandingkan target yang ditetapkan oleh bank saudara yaitu memberikan kredit dan jasa - jasa dalam lalu lintas pembayaran dan peredaran uang dalam masyarakat dengan realisasi penerimaan berdasarkan permohonan 


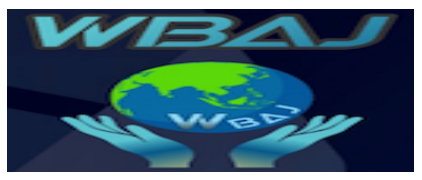

Volume 2 Issue 2, Desember 2020

https://ejournal.unsub.ac.id/index.php/bisnis

masyarakat dan penyelesaian permohonan tersebut. Dalam mejalankan tugasnya, Bank Saudara (persero) Tbk. Cabang subang mempunyai tujuan menjadi bank komersial terkemuka yang selalu mengutamakan pelayanan kepada kredit pensiun untuk menunjang peningkatkat ekonomi nasabah. Memberikan pelayanan prima kepala nasabah melalui jaringan kerja yang tersebah luas dan didukung oleh sumber daya manusia yang professional dengan melaksanakan praktek good corporate government, Memberikan keuntungan dan mafaat yang optimal kepada pihak - pihak yang berkepentingan (stakeholders).

Dengan dapat menunjang pembangunan disegala bidang, pemberian Kredit Pensiun untuk meningkatkan taraf hidup masyarakat. Seperti yang dikatakan oleh Kepala Bank Saudara Cabang sebagai berikut :

"...Tujuannya yang pertama yang jelas sebagai sebuah bank swasta. Kita ingin melayani nasabah secara baik, berkualitas dan disini dari awal kita sudah berkomitmen bahwa keunggulan dari bank Saudara dibandingkan bank -bank lainnya utamanya bahwa kita mengutamakan pelayanan yang cepat. Tapi pelayanan yang cepat kita tidak lepas juga dari faktor kehati-hatian tetap kita utamakan. Jadi nasabah dalam hal ini kenapa dalam memilih mencari pinjaman cenderung lebih memilih di Bank Saudara.

(Sumber: Wawancara, Agustus 2015)

Dari hasil penuturan Kepala bank saudara cabang subang disimpulkan bahwa Bank Saudara cabang subang mempunyai tujuan yaitu untuk melayani nasabah dengan baik dan berkualitas. Pelayanan yang diberikan oleh Bank Saudara cabang subang juga cepat. Dengan adanya pelayanan yang berkualitas, maka banyak banyak nasabah pensiun yang mengunakan pelayanan yang diberikan oleh Bank Saudara cabang subang.

Pelayanan yang diberikan oleh Bank Sauadara cabang subang yang dibahas dalam penelitian ini adalah pemberian kredit pensiun merupakan penyediaan uang atau tagihan yang dapat dipersamakan dengan itu, berdasarkan persetujuan dan kesepakatan pinjam meminjam antara bank dengan pihak lain yang mewajibkan pihak peminjam untuk melunasi hutangnya setelah jangka waktu tertentu dengan pemberian bunga. Pemberian kredit pensiunan bank saudara kantor cabang pembantu subang memberikan kredit kepada nasabah sesuai dengan kelompok masyarakat yang mengajukan kredit. Namun bukan berarti bank Saudara tersebut mengelompokan nasabah kedalam kelompok sosial tertentu, kredit pensiun adalah skema kredit atau pembiayaan untuk keperluan konsumtif atau untuk modal berwirausaha investasi yang khusus diperuntukan bagi pensiunan di bidang usahanya yang usahanya layak (feasible) namun mempunyai keterbatasan dalam pemenuhan persyaratan yang ditetapkan perbankan (belum bankable).

Kredit pensiun merupakan program pemberian kredit atau pembiayaan dengan nilai plafond pinjaman mulai Rp 5.000.000.- dengan pola pinjaman oleh perusahaan dengan besarnya coverage penjaminan maksimal 80\% dari gaji pensiun. Pemberian kredit pensiun yang diberikan oleh Bank Saudara cabang subang adalah Kredit pensiun dengan ketentuan sebagai berikut:

Kredit pensiun merupakan bentuk kredit yang diberikan kepada nasabah dan banyak digunakan oleh individu atau perorangan. Lama pinjaman 1 tahun plafond maksimal kredit pensiun adalah Rp 20.000.000,- ( dua puluh juta rupiah), bunga maksimal 


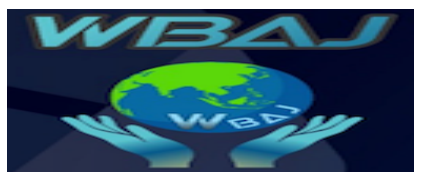

Volume 2 Issue 2, Desember 2020

https:// ejournal.unsub.ac.id/index.php/bisnis

adalah 22\% efektif pertahun. Ketika mengajukan pembiayaan atau kredit tidak diperlukan pengecekan Sistem Informasi Debitur

(SID). Jenis kredit pensiun di bank saudara kantontor cabang pembantu subang adalah penerima pensiun sendiri, penerima pensiun janda, penerima pensiun Anak Yatim / Yatim piatu. Legalitas yang harus dimiliki oleh nasabah adalah KTP dan KK. Ketentuan kredit pensiun Bank Saudara cabang subang

1. Angsuran pinjaman perbulan maksimum $80 \%$ dari gaji pensiun.

2. Cicilan bulanan dipotong dari gaji pensiun.

3. Plafond pinjaman mulai Rp. 5.000.000,00

4. Biaya provisi $1 \%$

5. Biaya Administrasi

6. Retensi 1 kali angsuran

7. Asuransi tergantung usia, jangka waktu kredit dan plafond

Permohonan pinjaman harus melampirkan persyaratan dengan dokumen pendukung yang diperlukan antara lain :

Umum

1. Usia saat jatuh tempo 73 tahun

2. Fotocofy KTP Suami/istri

3. Pas foto Suami/Istri 3x4 masing-masing 1(satu) buah.

4. Mengisi formulir Aplikasi permohonan Kredit

5. Fotocofy kartu Keluarga

Khusus

1. Slip pembayaran pensiun 1 ( satu) bulan terakhir

2. Asli SK pensiun

3. Fotocofy Karip / buku pembayaran pensiun (asli harus diperhatikan)

Penetapan target bagi organisasi merupakan sarana untuk memacu organisasi tersebut dalam mencapai tujuannya. Masalah yang lebih sulit lagi adalah bagaimana pencapaian target tersebut, karena untuk mencapai target tersebut dipengaruhi beberapa faktor. Bank sauadara cabang subang selalu melakukan peningkatan dalam berkinerja. Peningkatan itu saja untuk mendukung pencapaian target.

Seperti ungkapan RO (Relation Officer) Bank Saudara cabang subang sebagai berikut : '...Untuk taergetnya ya, di dalam pelayanan yang jelas kita selalu meningkatkan. Peningkatan setiap tahun ada. Kemudian yang kedua, target-target yang kita capai sesuai dengan rencana kerja itu kita selalu memperoleh hasil yang di atas dari rencana." (Sumber: Wawancara, Agustus 2015).

Dari ungkapan di atas, dapat memperlihatkan bahwa dalam mencapai target, tentu saja harus diimbangi dengan peningkatan pelayanan kepada nasabah. Bahkan peningkatan setiap tahunnya selalu ada. Pencapaian target bank saudara cabang subang sesuai dengan rencana kerja dan hasil yang diperoleh, selalu di atas dari rencana awal.

Berikut ungkapan kepala bank saudara cabang subang mengenai target yang ditetapkan oleh perusahaan, sebagai berikut: "..... Diatas, Diatasnya. Karena kan setiap tahun kita menuang di dalam rencana kerja. Dan hasilnya selalu diatasnya.'Jadi setiap tahun, bank saudara selalu menuang atau membandingkan antara target yang dicapai, dengan rencana kerja. Hasilnya dapat dikatakan diatasnya.Bank saudara cabang subang selalu mengupayakan meningkatkan daya 
saing dengan cara memberikan pelayanan yang sebaik-baiknya kepada seluruh nasabah. Mengenai penyelesaian permohonan dan tuntutan nasabah yang masuk ke bank saudara cabang subang, dapat dilihat dari ungkapan Castamer Service Bank saudara cabang subang sebagai berikut: " ...Setiap nasabah yang masuk ke bank saudara cabang subang selalu kami layani dengan semaksimal mungkin, tanpa memberatkan pemohon. Serta komplen maupun saran, pendapat dari nasabah selalu akomodasikan dan istilahnya kita carikan sebuah solusi bagaimana untuk peningkatan pelayanan yang lebih baik." Dari ungkapan - ungkapan di atas, dapat disimpulkan bahwa bank saudara cabang subang sudah baik dalam menyelesaikan permohonan dan tuntutan yang masuk dari nasabah. Bank saudara cabang subang dapat dikatakan sudah baik terlihat dari pelayanan-pelayanan kredit yang dikeluarkan. Produktivitas bank saudara cabang subang dapat dikatakan sudah baik terlihat dari produk-produk yang dikeluarkan, kenaikan jumlah nasabah baik nasabah kredit tabungan maupun deposito dan target pendapatan.

\section{Kualitas Pelayanan}

Seperti yang telah dijelaskan, bahwa kinerja organisasi bisnis juga dapat dilihat dari kualitas pelayanan yang diberikan organisasi bisnis tersebut kepada masyarakat. Kualitas pelayanan bank saudara cabang subang adalah bagaimana dalam memberikan pelayanan kepada nasabah dalam hal penyaluran kredit pensiun bank saudara.

Pelayanan yang diberikan oleh bank saudara cabang subang adalah dalam bentuk penyaluran kredit pensiun kepada nasabah adalah sebagai berikut :

1. Bank sauadara memberikan kredit kepada pensiun sendiri dan pensiun janda.

2. Kredit pensiun merupakan penyediaan uang atau tagihan yang dapat dipersamakan dengan itu, berdasarkan persetujuan dan kesepakatan pinjaman menjamin antara bank dengan pihak lain yang mewajibkan pihak peminjam untuk melunasi hutangnya setelah jangka waktu tertentu dengan pemberian bunga baik untuk keperluan konsumtif atau untuk modal berwirausaha dan investasi.

3. Debitur baru akan di cek pinjamannya melalui ( BI Cheking )

Harapannya agar pensiun tersebut mampu untuk memanfaatkan skema pendanaan yang berasal dari lembaga keuangan.

Pelayanan yang diberikan kepada nasabah dalam mendapatkan kredit pensiun cabang subang dengan cara sebagai berikut:

1. Nasabah mengajukan surat permohonan kredit pensiun kepada bank saudara dengan melampiri dokumen seperti : slip pembayaran pensiun 1 (satu) bulan terakhir, asli SK, fotocofy Karip / Buku pembayaran pensiun ( asli harus diperlihatkan kepada petugas bank)

2. Bank mengevaluasi atau analisa kelayakan permohonan kredit pensiun.

3. Apabila menurut bank kredit pensiun layak maka bank menyetujui permohonan kredit pensiun. Keputusan pemberian kredit pensiun sepenuhnya merupakan kewenangan bank.

4. Bank dan nasabah pensiun menandatangani perjanjian kredit atau pembiayaan.

5. Gaji pensiun akan di potong sesuai angsuran adalah kewajiban nasabah kepada bank sampai lunas. 
Selanjutnya, salah satu bentuk kualitas pelayanan adalah mengenai sarana dan prasarana yang ada di bank saudara cabang subang menyangkut pada pemberian pelayanan kepada masyarakat. Karena sebagai penyedia pelayanan, harus selalu memperhatikan sarana dan prasarana untuk suatu kegiatan pelayanan kepada nasabah kredit pensiun. Karena ketersediaan sarana dan prasarana yang baik, akan mempengaruhi persepsi nasabah terhadap kualitas pelayanan. Sarana dan prasarana tersebut sebagai contoh untuk ruang tunggu, ruang parker, computer dan lain-lain. Berikut gambar sarana dan prasarana bank saudara cabang subang terhadap nasabah : Tentang sarana dan prasarananya. Berikut tanggapan dari bapak imbron (Security) :" ...Ya. ruang tunggunya sudah cukup bagus. Kursinya cukup banyak, ada TVnya, sudah berAC. Jadi kalau pas banyak antrian, kita nyaman dan tidak cepat bosan. Untuk tempat parkir, kebanyakan yang datang itu bawa motor. Jarang yang bawa mobil . paling mobil-mobil yang parkir itu punya pengawainya. Jadi untuk parkir cukup. Kalau buat mobil ya masih kurang luas. Tapi mau gimanan lagi, keadaan bagunannya juga memang sempit. ( sumber : wawancara, Agustus 2015)

Seperti yang diungkapkan oleh customer service berikut ini :'...Ruang tunggu kita sudah representative, karena di situ ada AC, kemudian ada TV, juga tempat duduk yang cukup nyaman. Kemudian untuk tempat parkir, juga cukup baik terutama untuk kendaraan roda dua karena tempat kita relatif cukup luas ( sumber : wawancara, Agustus 2015).Penyataan di atas menunjukan bahwa bank saudara cabang subang juga memperhatikan sarana dan prasarana dan prasarana dengan tujuan agar nasabah yang datang merasa nyaman dan menciptakan kepuasan nasabah kredit pensiun.Ruang tunggu yang dilengkapi TV, AC dan jumlah kursi yang cukup dapat membuat nasabah nyaman saat menunggu giliran mendapatkan pelayanan. Hanya saja untuk tempat parkir, memang terbatas karena memang lokasi bank saudara relatif cukup luas.Selain itu sarana yang ada di bank saudara cabang subang adalah perangkat computer. Hampir semua kegiatan di bank saudara sudah menggunakan komputer. Berkaitan dengan hal ini, kepala bank saudara menjelaskan sebagai berikut :"...hampir semua kegiatan disini sudah menggunakan computer. Saya rasa computer disini sudah memadai. Kita juga selalu berusaha mengikuti perkembangan teknologi. Karena teknologi sekarang ini sangat cepat sekali berkembang. Walau kita tidak cepat menyesuaikan, tapi kita tetap berusaha mengikutinya. ( sumber : wawancara, Agustus 2015).Costomer service menjelaskan hal yang serupa sebagai berikut :"...kita selalu mengikuti perkembangan teknologi. Setiap tahun kita selalu mengunakan peralatan yang kita punya." (sumber : wawancara, Agustus 2015). Demikian halnya dengan teller bank saudara cabang subangmenyatakan hal yang serupa sebagai berikut: "...Kalau computer tiap-tiap bagian disini sudah mengunakan computer terutama bidang perijinan. Jumlahnya juga sudah memadai. Karena dengan adanya computer, kita lebih bisa bekerja cepat dan tentu saja mempersingkat waktu." Semua kegiatan di bank saudara cabang subang sudah menggunakan computer. Mengenai jumlah, mencukupi, terbukti dari tiap-tiap bagian, sudang menggunakan computer. Computer dinilai dapat mempermudah pekerjaan dan menghemat waktu. Semua ini bertujuan kembali supaya dalam memberikan pelayanan bisa optimal. Keterangan tersebut menunjukan jumlah fasilitas atau sarana yang di miliki bank saudara cabang subang. Sarana yang 


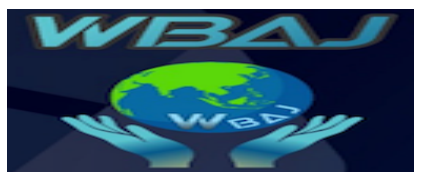

Volume 2 Issue 2, Desember 2020

https://ejournal.unsub.ac.id/index.php/bisnis

dimiliki sudah mencukupi dan sangat mempengaruhi pegawai dalam memberikan pelayanan dan melaksanakan pekerjaan.

Dari wawancara di atas dapat disimpulkan bahwa jumlah computer yang ada di bank saudara cabang subang sudah cukup memadai. Di tunjukan bahwa di tiap-tiap bagian sudah mengunakan computer. Computer dapat dianggap suatu alat yang penting apalagi untuk bank saudara cabang subang. Dengan menggunakan computer data bisa diolah tentu saja dengan waktu yang hemat, mempermudah pegawai dalam melaksanakan pekerjaannya dan memberikan pelayanan kepada nasabah. Bank saudara cabang subang sebagai organisasi penyedia jasa pelayanan pastinya dituntut untuk memberikan pelayanan yang maksimal dan berkualitas. Untuk itu, jumlah pegawai sangat mempengaruhi dalam menciptakan pelayanan yang berkualitas. Karena pegawai adalah pelaksana kegiatan dalam memberikan pelayanan kepada nasabah kredit dengan terpenuhinya jumlah pegawai, diharapkan semua pekerjaan dapat diselesaikan. Jumlah pegawai di bank saudara cabang subang sebanyak orang yang di bagi dalam berbagai bagian. Jumlah pegawai tersebut dirasa sudah cukup. Kualitas pelayanan sebenarnya dapat dikatakan tergantung pada kemampuan karyawan dalam memberikan pelayanan kepada nasabah. Demi terciptanya pelayanan yang berkualitas, maka dibutuhkan kemampuan, kehandalan para pegawai dalam memberikan pelayanan kepada nasabah permohonan kredit pensiun. Kemampuan disini adalah kemampuan teknis dan non teknis misalkan saja, sikap keramahan tamahan, kesopanan dalam memberikan pelayan kepada nasabah. Kemampuan pegawai dapat dilihat dari ungkapan kepala bank saudara cabang subang yang mengungkapkan : "...kemampuan dari segi pendidikan formal itu di mayoritas s1, sisanya D3 dan SLTA, kemampuannya adalah banyak sekali, salah satunya ada di bidang perbankan..." Selanjutnya akan dipaparkan tentang tanggapan nasabah kredit pensiun bank saudara cabang subang, ibu kokom komariah mengemukakan tanggapan sebagai berikut :"...Kemampuan pegawainya sudah cukup baik. Mereka menguasai bidang yang mereka tangani. Mereka juga ramah, sopan dan tidak membeda-bedakan nasabah yang datang untuk memperoleh pelayanan." Hal senada disampaikan oleh bapak kusnadi yang juga sebagai berikut :"...Menurut saya kemampuan pegawainya sudah baik dilihat dari penguasaan di bidangnya masing-masing. Jika mendapati kesulitan, mereka segera mengkoordinasikan dengan bagian terkait." Dari hasil wawancara dengan nasabah kredit pensiun bank saudara cabang subang tentang kemampuan pegawai dapat disimpulkan bahwa kemampuan mereka dalam memberikan pelayanan sudah baik dan perlu untuk dipertahankan sehingga nasabah kredit pensiun akan puas terhadap pelayanan yang mereka dapat.

Selain kemampuan pegawai bank saudara cabang subang, penyelesaian pelayanan nasabah kredit pensiun ajukan juga sudah sesuai dengan ketentuan yang berlaku, seperti yang disampaikan oleh kepala bidang perijinan sebagai berikut:"... disini ada di SOPnya, tapi yang jelas kita sudah berkomitmen bahwa untuk pelayanan khususnya untuk pelayanan kredit pensiun kepada nasabah, pelayanan kita One Day Service." Wawancara di atas menunjukan bahwa pelayanan di bank saudara cabang subang dapat dikatakan cepat. Karena menganut system One Day Servise.Selain itu untuk menciptakan kualitas pelayanan yang maksimal. Dapat dinilai dari proses 


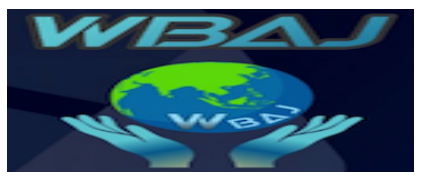

Volume 2 Issue 2, Desember 2020

https://ejournal.unsub.ac.id/index.php/bisnis

pinjaman kredit pensiun. Karena hal tersebut dapat menberikan rasa kepercayaan nasabah kepada bank saudara cabang subang.

Responsivitas

Bank saudara cabang subang adalah salah salah satu organisasi pelayanan bisnis yang selalu berusaha memberikan pelayanan terbaik berupa pelayanan prima agar dapat memenuhi kebutuhan dan harapan nasabah. Untuk itu dituntut bank saudara cabang subang harus selalu tanggap disampaikan nasabah. Konsep responsivitas mengarah pada pertanggung jawaban organisasi bisnis dalam memberikan pelayanan kepada nasabah. Respon yang diharapkan dari pengguna pelayanan kepada bank saudara cabang subang adalah daya tanggap bank saudara cabang subang dalam melayani dan memenuhi kebutuhan nasabah dengan cepat dan tanpa prosedur yang berbelitbelit serta tepat waktu. Berikut gambar repon pegawai yang baik terhadap nasabah kredit pensiun. Sikap responsif dari bank saudara cabang subang dapat dilihat dari bagaimana bank saudara cabang subang dalam memberikan dan menyediakan sarana pelayanan. Kebutuhan pelayanan disini mencakup segala sarana yang dibutuhkan pegawai bank saudara untuk melayani pelanggan. Untuk itu bank saudara cabang dituntut untuk mempunyai fasilitas yang memadai yang akan menciptakan pelayanan yang berkualitas. Sikap responsif bank saudara cabang subang dapat dilihat dari hasil wawancara dengan Bapak Agus Budiarto, SE Bagian umum kepegawaian berikut ini; ... Kita adalah lembaga pelayanan publik yang selalu berusaha untuk memberikan pelayanan terbaik.kita juga menerapkan one day service.sehingga di harapkan pelayanan yang kami berikan itu cepatkita juga berusaha untuk memenuh tntutan atow kebutuhan masyarakat."

Sikap responsife juga harus diterapkanpada saat pemeriksaan nasabah yang ingin meminjamkan kredit pensiun jadi jangan sampei pegawai tersebut tidak tahu usahanya apa yang di jalankan nasabah.pada dasarnya kerdit pensiun bermasalah merupakan kondisi yang sering kali terjadi pada perbankan yaitu sebagai resiko dari penyaluran kredit bank yang bersangkutan. Walowpun kredit bermasalah seringkali sulit untuk di hindari namun bank harus tetap mengelolanya secara hati - hati dan sedapat mungkin di minimalkan resiko sehingga dapat memberikan keuntungan bagi bank.

Pengolaan kredit pensiun bermasalah harus bersifat antipatif dan berdisiplin dengan demikian kredit pensiun bermasalah di mulai dengan perkenalan dini dan tindakan perbaikan segera. Kredit pensiun bermasalah adalah kredit pensiun yang diklasifikasikan kurang lancar (KL), diragukan (D), dan macet. Kredit pensiun bermasalah pada bank saudara cabang subang adalah kekurang telitian pihak bank dalam melakukan analisis kredit. Selain itu dari pihak nasabah adalah menurunnya usaha debitur, pengelolaan usaha debitur tidak berjalan baik serta adanya anggapan dari nasabah bahwa kredit pensiun merupakan bantuan dari negara.

Disinilah pegawai harus tanggap dalam menghadapi nasabah dan dapat menyelesaikan keluhan-keluhan yang disampaikan nasabah dengan demikian nasabah menjadi lebih mengerti tentang apa yang dinamakan kredit pensiun agar pelaksanaan kredit pensiun ini tidak berjalan dengan lancar maka bank saudara cabang subang melakukan usaha - usaha sebagai berikut :

1. Melaksanakan sosialisasi kredit pensiun kepada nasabah dan kepada pihak yang terkait, bahwa kredit pensiun adalah produktif yang menekan kelayakan usaha. 


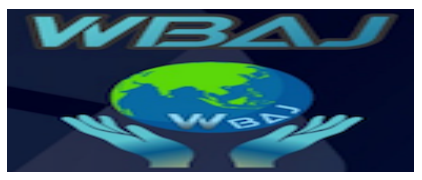

Volume 2 Issue 2, Desember 2020

https://ejournal.unsub.ac.id/index.php/bisnis

2. Kepala cabang melakukan monitoring dan evaluasi atas pelayanan kredit pensiun.

Dengan responnya pegawai dari bank saudara cabang subang maka diharapkan akan mengurangi keluhan nasabah seperti, waktu tunggu lama untuk memperoleh realisasi kredit kurang jelasnyainformasi untuk memperoleh kredit sehingga calon nasabah merasa dipermainkan. Sementara itu kepala cabang subang juga mengemukakan hal sebagai berikut :' ...Sikap responsive kita dalam menanggapi kebutuhan nasabah sudah bagus. Sistem kerja kita juga menuntut agar pegawai harus lebis responsive. Kita juga selalu memberikan informasi - informasi kepada nasabah tetapi terkadang dalam menanggapi keluhan nasabah kita lansung ditindak lanjuti " Sikap responsive juga dapat dilihat dari tanggapan nasabah pengguna pelayanan seperti yang diungkapkan oleh bapak amin warga subang....menurut saya pihak bank saudara cabang subang sudah cukup tanggap dengan kebutuhan maupun keluhan nasabah. Dalam memberikan pelayanan mereka selalu responsif terhadap nasabah sehingga mempercepat proses pelayanan ". Berdasarkan hasil wawancara diatas menunjukan bahwa bank saudara cabang subang sudah cukup tangga dalam memenuhi kebutuhan pelayan. hal ini dapat terlihat dari banyak nya keluhan keluhan dari nasabah dapat pelayanan dengan baik dan dapat ng menyingkapi keluhan - keluhan dari nasabah. Selain itu, selama ini jarang sekali keluhan -keluhan yang di sampaikan oleh nasabah, seperti yang di ungkapkan kepala cabang subang sebagai berikut: " ...Selama ini kita berindikasi jarang nasabah yang mengajukan complain. Kalau pun ada kita dapat menyelesaikan nya dengan baik ( sumber: wawancara, Agustus 2015 ). Sementara itu, tanggapan dari ibu yanti warga cigadung tentang keluhan fasilitas ruang tunggu kepada bank saudara cabang subang sebagai berikut:" ...saya pernah menyampaikan keluhan Kepada bank saudara cabang subang mengenai fasilitas ruang tunggu. Pihak bank saidara cabang subang mau mendengarkan keluhan saya dengan baik. Namun tidak langsung direalisasikan," . Tanggapan serupa disampaikan oleh bapak Larso warga cikondang subang tentang jaminan kredit sebagai berikut :

Dari beberapa hasil wawancara di atas tentang bank saudara cabang subang dapat dikatakan belum maksimal dan masih perlu ditingkatkan. Tidak lepas dari itu, bank saudara cabang subang tentu saja hus tetap meningkatkan upaya-upaya agar nasabah puas dengan pelayanan yang diberikan. Bank saudara cabang subang juga harus tetap lebih maksimal dalam menanggapi keluhan nasabah.

\section{Responsibilitas}

Responsibiltas berhubungan dengan sejauh mana organisasi melaksanakan segala kegiatannya sesuai dengan prinsip - prinsip dan peraturan yang benar dengan standart professional dan kompetensi teknis yang dimiliki dalam rangka pencapaian tujuan secara optimal. Jadi seperti yang telah dibahas dimuka bahwa responsibilitas dari bank saudara cabang subang adalah kemampuan bank saudara cabang subang dalam melaksanakan tugas dan tanggung jawabnya sesuai dengan standart professional dan kompetensi aparatur perusahaan dengan mengarahkan Sumber Daya yang dimiliki untuk mencapai tujuan yang ditetapkan.

Dalam memberikan pelayanan kepada nasabah, bank saudara cabang subang selalu berdasarkan prosedur yang sudah ada, yaitu tertuang dalam SOP (Standar operation 


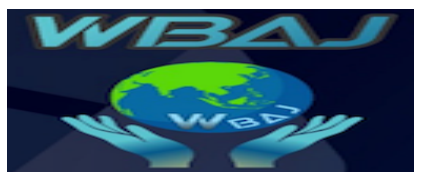

Volume 2 Issue 2, Desember 2020

https://ejournal.unsub.ac.id/index.php/bisnis

Prosedure). Sehingga dalam memberikan pelayanan tidak terjadi penyimpangan. Seperti yang diungkapkan oleh costomer service bank saudara cabang subang sebagai berikut :" ...Untuk prosedur tentu saja ada ...Tertuang di SOP ( Standart Operation Prosedure)." Dalam memberikan pelayanan tentu saja bank saudara cabang subang selalu melalui prosedur tersebut. Seperti ungkapan costomer bank saudara sebagai berikut : "...kita ya selalu melalui prosedur yang sudah tertuang di SOP, dalam memberikan pelayanan kepada nasabah." Berdasarkan wawancara di atas, bank saudara cabang subang selalu menaati prosedur dalam memberikan pelayanan kepada nasabah sperti yang ada dalam SOP ( Standart Operation Prosedure). Sehingga pelayanan yang diberikan dapat tetap berkualitas. Prosedur yang harus dilewati oleh calon debitur adalah sebagai berikut :

\section{Tahap Permohonan Kredit}

Calon debitur mengajukan permohonan kredit pensiun secara tertulis kepada pihak bank saudara cabang subang. Calon debitur kredit pensiun datang ke kantor bank saudara,kemudian dengan dibantu oleh customer formulir pengajuan permohonan kredit pensiun yang sudah disediakan pihak bank, kemudian ditandangani oleh pemohon. Calon debitur kredit pensiun diharuskan memenuhi persyaratan yang telah ditetapkan dalahal pengajuan permohonan kredit pensiun. kredit pensiun diperkenalkan sebagai kredit yang mudah didapat,maka yang ditetapkan sangat sederhana syarat-syarat yang perlu disertakan adalah bukti identitas diri berupa potokopi kartu tanda penduduk [KTP] potokopi kartu kluarga [Kk]

Dan surat keterangan usaha.

\section{Tahap analisis kredit/tahap pemeriksaan}

Berdasarkan arahan bank saudara sebagai mana termuat dalam SK Direksi bank sodara No 27/162/KEP/DIR tanggal 31 september 2015,setiap permohonan kredit yang telah memenuhi syaratharus dianalisis secaa tertulis bank sodara cabang subang dalam melakukan analisis kredit pun mempunyai kebijakan sendiri yang tentu tetap berpedoman pada arahan bank Indonesia. Laporan keuangan calon debitur merupakan salah satu data pokok mutlak hal analisis. Pada tahap pemeriksaan, setelah syarat - syarat dilengkapi, pihak bank saudaracabang subang dalam hal ini RO ( Relation Officer) akan melakukan checking peserta peninjauan langsung ke lapangan tentang layak atau tidaknya calon debitur kredit pensiun diberikan pinjaman dengan menanyakan hal - hal yang berkaitan dengan permohonan kredit pensiun tersebut antara lain :

1. Mencocokan fotocofy bukti diri KTP ( Kartu tanda penduduk ) atau indentitas lain sesuai dengan aslinya.

2. Menanyakan hal - hal yang berhubungan dengan usaha calon debitur pihak kredit pensiun. Misalkan : tentang modal usaha, investasi, tentang pinjaman pada pihak lain, dan lain -lain.

\section{Tahap Pemberian putusan kredit}

Tahap ini, calon debitur akan memperoleh keputusan kredit yang berisi persetujuan akan adanya pemberian kredit pensiun sesuai permohonan yang diajukannya. Keputusan persetujuan permohonan kredit berupa mengabulkan sebagian atau 


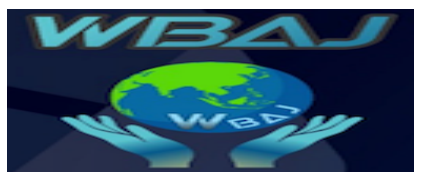

Volume 2 Issue 2, Desember 2020

https://ejournal.unsub.ac.id/index.php/bisnis

seluruh permohonan kredit dari calon debitur. Pihak bak saudara cabang subang akan memberitahukan kepada calon debitur untuk mengkonfirmasi kembali beberapa hari menurut hari yang telah ditentukan oleh pihak bank setelah pengajuan permohonan kredit. Biasanya pemberian putusan dilakukan 3- 5 hari setelah pendaftaran permohonan kredit pensiun. pada bank saudara cabang subang, sebelum pemberian putusan kredit, kepala bank Saudara cabang subang wajib meneliti dan memastikan bahwa dokumen - dokumen yang berkaitan atau yang mendukung pemberian keputusan kredit masih berlaku lengkap, sah, dan berkekuatan hukum.

Tahap pencairan Kredit atau Akad Kredit

Setiap proses pencairan kredit (disbursrement) harus terjamin asas aman, terarah, dan produktif dan melaksanakan apabila syarat yang ditetapkan dalam perjanjian kredit telah dipenuhi oleh permohon kredit. Setelah semua persyaratan terpenuhi dan pemberian kredit diikat oleh perjanjian kredit maka debitur dapat mengambil dana pinjaman yang telah dipermohonkan kepada bagian teller bank saudara cabang subang. Tahap akad kredit atau pencairan meliputi beberapa tahap yaitu tahap persiapan pencairan, penandatanganan perjanjian pencairan kredit, fiat bayar dan pembayaran pencairan kredit.

Kredit pensiun adalah program yang digagas oleh perusahaan. Konsep dasar kredit pensiun ini adalah kredit perbankan yang dijamin perusahaan swasta. Untuk melaksanakan penjaminan kredit pensiun bank saudara menunjuk penjamin yaitu Asuransi Kredit Indonesia ( Askrindo ) dan Asuransi jasa Indonesia ( Jasindo). Namun, besarnya jaminan yang diberikan bank saudara tidaklah utuh $100 \%$ dari nilai kredit pensiun melainkan hanya 70\% sedangkan 30\% menjadi resiko bank pelaksana. Dalam hal ini penulis mencoba untuk mengetahui prosedur permohonan program kredit pensiun serta permasalahan hukum apa yang timbul karenanya.

\section{Akuntabilitas}

Akuntabilitas dalam penyelenggaraan pelayanan bisnis adalah suatu ukuran yang menunjukan seberapa besar kesesuaian penyelenggaraan pelayanan dengan petunjuk pelaksana yang menjadi dasar atau pedoman penyelenggaraan pelayanan kepada pihak yang memiliki kewenangan untuk meminta pertanggung jawaban tersebut. Akuntabilitas bank saudara cabang subang dapat diartikan sebagai bentuk pertanggung jawaban atas penyelenggaraan pelayanan kepada pihak yang memiliki hak dan wewenang untuk meminta pertanggung jawaban tersebut. Pertanggung jawaban bank saudara cabang subang adalah kepada kepala cabang dan kepala pusat bank saudara.

Bank Saudara cabang subang menyusun Laporan pertanggung jawaban atas Penguasaan dan Perkembangannya sebagai realisasi pelaksanaan program kerja dan Rencana Kerja Tahunan dan Rencana Pendapatan dan Belanja Tahun Buku 2012 yang telah disyahkan oleh Kepala Cabang Bank Saudara Subang pada tanggal dengan Surat Keputusan Kepala Cabang Bank Saudara Subang Nomor 5 39/807 Tabun 2012. Pertanggungjawaban dan Bank saudara dapat diketahui dan pendapat Kepala Cabang sebagai berikut: “...Yang jelas adalah pertanggungjawaban kepada perusahaan dan dana dan pihak ketiga selaku Penjamin Kredit dan nasabah bertanggungjawab terhadap peredaran uang maupun perjalanan Bank Saudara dengan pihak-pihak lain sebagai contoh kepada bank-bank umum, pemerintah 


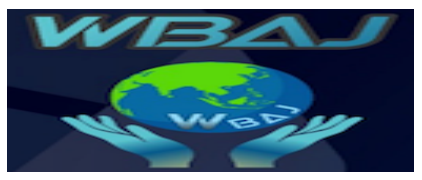

Volume 2 Issue 2, Desember 2020

https://ejournal.unsub.ac.id/index.php/bisnis

daerah, badan pengawas, komisaris dan lain sebagainya." Seperti ungkapan di atas, pertanggung jawaban Bank Saudara Cabang Subang antara lain adalah kas daerah dan dana dan pihak ketiga (nasabah), bertanggungjawab terhadap peredaran uang maupun perjalanan Bank saudara kepada pihak-pihak lain. Pertanggungjawaban Bank Saudara adalah kepada Kepala Cabang, dan Penjamin Kredit. Hal ni juga. Disampaikan oleh Teller Bank Saudara cabang subang berikut ini: Pertanggungjawaban Bank Saudara kepada Perusahaan dan Penjamin Kredit ." (Sumber: wawancara, 28Agustus 2015). Dan apa yang disampaikan oleh Kepala Bank Saudara Cabang Subang di atas, dapat menjelaskan bahwa pertanggungjawaban Bank Rakyat Saudara itu kepada Pemerintah. Ada tiga (3) pilar penting dalam pelaksanaan program ini Pertama adalah pemerintah, yaitu Bank Indonesia (BI)

Dan Departemen Teknis (Departemen Keuangan, Departemen Pertanian, Departemen Kehutanan, Departemen Kelautan dan Perikanan, Departemen Perindustrian, dan Kementerian Koperasi).Pemerintah berfungsi membantu dan mendukung pelaksanaan pemberian berikut penjaminan kredit.Kedua, lembaga penjaminan yang berfungsi sebagai penjamin atas kredit dan pernbiayaan yang disalurkan oleh perbankan.Ketiga, perbankan sebagai penerimajaminan berfungsi menyalurkan kredit pensiun. Pertanggungjawaban Bank Saudara cabang subang, terlihat dan pendapat Kepala Bank Saudara cabang subang sebagai berikut: “....Yang jelas pertama membantu masyarakat ekonomi lemah di Daerah, meningkatkan perekonomian dan stabilitas ekonomi masyarakat pada khususnya, umumnya adalah masyarakat ekonomi Iemah. Dan sekaligus melihat pangsa pasar di tingkat persaingan perbankan lainnya, karena Bank Saudara cabang subang bergerak sebagai lembaga keuangan yang menyangkut tentang kredit sesuai dengan aturan perusahaan." Pendapat di atas menunjukkan dalam perjalannya, Bank saudara sebagai lembaga keuangan tidak serta merta mengutamakan keuntungan sernata, tetapi juga kembali kepada rnasyarakat. Bank Saudara cabang subang juga memikirkan nasabah terutama kalangan ekonomi lemah khususnya di wilayah subang. Semua itu bertujuan untuk meningkatkan perekonomian stabilitas ekonomi nasabah Subang pada umumnya dan masyarakat ekonomi lemah pada khususnya.

Pada dasarnya kredit pensiun bermasalah merupakan kondisi yang sering kali terjadi pada perbankan yaitu sebagai risiko dan penyaluran kredit bank yang bersangkutan. Walaupun kredit bermasalah seringkali sulit untuk dihindari namun bank harus tetap rnengelolanya secara hati-hati dan sedapat mungkin diminimalkan resiko sehingga dapat memberikan keuntungan bagi bank. Pengelolaan Kredit pensiun bermasalah harus bersifat antipatif, proaktif dan berdisiplin dengan demikian kredit pensiun bermasalah dimulai dengan pengenalan dini dan tindakan perbaikan segera. Kredit pensiun

berrnasalah adalah kredit pensiun yang dikiasifikasikan kurang lancar (KL), diragukan (D), dan macet.

Penyebab kredt pensiun bermasalah pada Bank saudara cabang subang adalah kekurang telitian pihak bank dalam melakukan analisis kredit. Selain itu dan pihak nasabah adalah menunlnnya usaha debitur, pengelolaan usaha debitur tidak benjalan baik serta adanya anggapan dan nasabah bahwa kredit pensiun merupakan bangian dan pemerintah. Bank selalu berusaha untuk mencari jalan keluar yang lebih praktis, efisien dan efektif dalam hal terjadi kredit bermasalah agar lebih menghemat waktu 


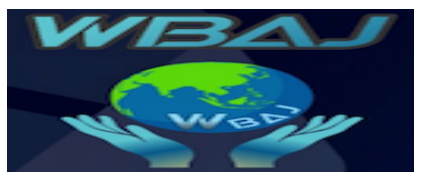

Volume 2 Issue 2, Desember 2020

https://ejournal.unsub.ac.id/index.php/bisnis

dan biaya. Seperti haInya yang dilakukan Bank saudara yaitu dengan melakukan beberapa tindakan penerobosan agar kerugian akibat kredit bermasalah dapat sedikit tertutupi. Upaya yang dilakukan Bank saudara cabang subang dalam mengatasi kredit bermasalah adalah melakukan penagihan secara terus menerus.

Memperketat analisis kredit dilakukan dalam upaya pencegahan untuk menghindari adanya usaha yang fiktif. Maksudnya bahwa tujuan debitur mengajukan permohonan kredit pensiun bukan untuk usahanya tetapi untuk tujuan lain. Menghadapi debitur yang lalai dalam rnelaksanakan pembayaran adalah hal yang biasa terjadi, untuk itu seorang $\mathrm{RO}$ atau (Relation Officer) mempunyai cara sendiri untuk menghadapinya, yaitu dengan pembicaraan dua pihak secara persuasif yang bersifat kekeluargaan. Apabila keadaan debitur memang tidak memungkinkan untuk melakukan pembayaran, maka kredit usaha rakyat dapat diperpanjang jatuh tempo perlunasannya. Yang menjadi pertimbangan pihak bank saudara Kuwarasan adalah program Kredit ini ditunjukan untuk rakyat kecil sehirigga memperkecil kemungkinan untuk memberatkan mereka.

\section{Kesimpulan}

Kinerja Pegawai Dalam Penyaluran Kredit Pensiun Bank Saudara (Persero) Tbk. Cabang Subang diukur menggunakan lima indikator yaltu produktivitas, kualitas pelayanan, responsivitas, responsibilitas dan akuntabilitas. Berdasarkan hasil pembahasan yang telah diuraikan mengenai Kinerja pegawal Kinerja Pegawai Dalam Penyaluran Kredit Pensiun Bank Saudara (Persero) Tbk. Cabang Subang menunjukkan bahwa:

1. Produktivitas Bank Saudara (Persero) Tbk. Cabang subang dalam penyaluran kredit pensiun sudah baik. Dilihat dan kenaikan jumlah nasabah, dan pencapaian target pendapatan sesuai dengan rencana kerja bahkan selalu di atas rencana awal. Selain itu Bank Saudara (Persero) Tbk. Cabang Subang selalu cepat dalam penyelesaian permohonan.

2. Kualitas Pelayanan Bank Saudara (Persero) Tbk. Cabang Subang sudah tercapai secara maksimal. Sarana dan prasarana yang dimiliki sudah lengkap, mengikuti perkembangan teknologi, sikap ramah tamah, sopan pegawai memberi kenyamanan nasabah. Kemampuan pegawai mayoritas berpendidikan S1. Bank sodara (Persero) TBK Cabang Subang menerapkan system One Day Service, sehingga pelayanan dapat lebih cepat diberikan kepada masyarakat. Selain itu ditunjukkan pada pengembalian uang atau tabungan yang sesuai dengan kebutuhan masyarakat.

3. Responsivitas Bank sodara (Persero) Tbk. Cabang Subang dapat dikatakan belum maksimal dan masih perlu ditingkatkan. Sudah ada respon yang positif terhadap keluhan dan pengaduan yang disampaikan oleh masyarakat terkait pelayanan. Sebagian besar keluhan dan masyarakat berkaitan dengan kuantitas, kualitas pelayanan yang diberikan. Pihak Bank sodara (Persero) TBk.Cabang Subang berupaya menanggapi dengan baik keluhan-keluhan yang masuk. Hanya saja pengaduan tersebut tidak segera ditindak lanjuti karena segala keputusan dan cabang harus menunggu pengesahan dan cabang sehingga masyarakat merasa 
bahwa Bank saudara (Persero) Tbk.Cabang Subang tidak merespon keluhan mereka.

4. Responsibilitas bank saudara (Persero) tbk. Cabang Subang dapat dikatakan sudahbagus.Hal ini terlihat baik.dan prosedur pelayanan yang diberikan oleh Bank saudara cabang subang (Persero)Tbk. Cabang Subang sudah tertuang dalam SOP (Standart Operation Prosedure). Selain itu kemampuan Bank saudara (Persero) Tbk.Cabang Subang dalam melaksanakan tugas dan tanggungjawabnya untuk meningkatkan kualitas sangat diperhatikan

5. Akuntabilitas Bank saudara (Persero) Thk.Cabang Subang adalah dalam bentuk Laporan Laba Rugi, yang telah diaudit Akuntan Publik kepada Dewan Pengawas/ Dewan Komisaris dan diteruskan Pertama adalah pemerintah, yaitu Bank Indonesia (BI) dan Departemen Teknis (Departemen Keuangan, Departemen Pertanian, Departemen Kehutanan, Departemen Kelautan dan Perikanan, Departemen Perindustrian.bank saudara berfungsi membantu dan mendukung pelaksanaan pemberian berikut penjaminan kredit.Kedua, lembaga penjaminan yang berfungsi sebagai penjamin atas kredit dan pembiayaan yang disalurkan oleh perbankan.Ketiga, perbankan sebagai penerima jaminan berfungsi menyalurkan kredit pensiun.

\section{Referensi}

Dwiyanto. 2002. Penilaian Kinerja Organisasi Pelayanan. Grafindo Persada. Yogyakarta: Pusat Studi dan Kependudukan dan Kebijakan UGM

Hasibuan.2005. Manajemen Kinerja. Cetakan Pertama. Pustaka Pelajar: Yogyakarta.

Hessel Nogi S. Tangkilisan. 2005. Manajemen Pemasaran. Jakarta : PT Gramedis Pustaka.

Mahmudi. 2013. Manajemen Kinerja Sektor Bisnis. Yogyakarta : Unit Penerbit dan Percetakan Sekolah Tinggi Ilmu Manajemen YKPN.

Mohamad Mahsun .2006 Pengukuran Kinerja Sektor Bisnis. Yogyakarta : BPFE.

Mangkunegara.2006. Manajemen Pelayanan Umum di Indonesia. PT. Bumi Aksara: Jakarta

Suyadi Prawirosentono..1999. Manajemen Sumber Daya Kebijakan Kinerja Karyawan. Yogyakarta: BTFE

Soerjono Soekanto. 1993. Kamus Sosiologi. Jakarta : Rajawali Pres

Wibowo. 2007. Manajemen Kinerja. Jakarta : PT. Raja Grafindo Persada

Widodo. 2008. Birokrasi Berbasis Kinerja. Malang : Bayumedia Publishing 